\title{
VERIFICATION OF THE RELATIONSHIP BETWEEN FDI AND GDP IN POLAND
}

\author{
Aneta KOSZTOWNIAK \\ (Received: 7 August 2014; revision received: 8 October 2014; \\ accepted: 13 May 2015)
}

The paper analyses the impact of the factors of production on economic growth in Poland in the years 1992-2012, with particular focus on the impact of foreign direct investment (FDI), and strives to verify whether a causality relationship occurred between GDP and FDI, i.e. whether high GDP dynamics attracted FDI inflows and whether this investment contributed to GDP growth. The Vector Error Correction Method impulse responses and variance decomposition analysis confirmed the bi-directional relationships between FDI and GDP in Poland. However, the impact of GDP on attracting FDI inflows to Poland is stronger than that of FDI on GDP growth. Polish developmental policy should concentrate on three essential determinants (pillars) of growth, namely employment growth, attracting FDI (with emphasis on improvement in the type of inflowing investment), and increasing the value and productivity of domestic investment.

Keywords: FDI, GDP, Poland, bilateral causality, VECM, the response function, variance decomposition

JEL classification indices: C50, C52, F41, F43, O11

Aneta Kosztowniak, Assistant Professor at the Faculty of Economics and Legal, Department of Economic Policy and Banking, Kazimierz Pulaski University of Technology and Humanities in Radom, Poland. E-mail: aneta.kosztowniak@wp.pl 


\section{INTRODUCTION}

The two decades that have passed since the beginning of the transformation in Poland seem to be a sufficient time to examine the correlations between FDI and GDP, taking into account the fact that, unlike indirect investment (short-term capital), the influence of FDI on the economy is of a long-term character.

The aim of this paper is to analyse the effect of the factors of production on economic growth in Poland in the years 1992-2012, with particular attention to the effect of FDI and to verify whether there are any cause-and-effect relationships between GDP and FDI, i.e. whether high GDP dynamics attract FDI inflows and whether this type of investment contributes to GDP growth.

The paper uses Vector Error Correction Method (VECM), based on the neoclassical Cobb-Douglas production function. Data were taken from the OECD.

\section{MUTUAL RELATIONSHIPS BETWEEN FDI AND ECONOMIC GROWTH - THEORETICAL APPROACH}

In theory, there are several potential ways in which FDI can cause growth. Representatives of the Keynesian school point out two effects: a short-term (direct) effect influencing changes in domestic product and a long-term (indirect) one connected with knowledge transfer and diffusion, the pressure of growing competition in domestic enterprises in view of the competition from foreign companies, and effects related to the diffusion of knowledge supporting innovation (Keynes 1936; Wojtyna 2000).

The Solow-type standard neoclassical growth models (Solow 1999) suggest that FDI increases the capital stock and thus promotes growth in the host economy by financing capital formation (Brems 1970; Kida 2014). FDI promotes economic growth by increasing the volume of investment and/or its efficiency. Admittedly, in neoclassical growth models with diminishing returns to capital, FDI has only a "short-run" growth effect, as countries move towards a new steady state (although the time frame involved in this adjustment can be quite long). Accordingly, the impact of FDI on growth is identical to that of domestic investment. In endogenous growth models, in contrast, FDI is often assumed to be more productive than domestic investment. The logic behind this is that FDI encourages the incorporation of new technologies in the production function of the host economy (Borensztein et al. 1998). In this view, FDI-related technological spillovers offset the effects of diminishing returns to capital and keep the economy on a higher long-term growth path. Moreover, endogenous growth models imply that FDI can promote long-run growth by augmenting the existing stock of 
knowledge in the host economy through labour training and skill acquisition on the one hand, and through the introduction of alternative management practices and organizational arrangements on the other (de Mello 1997). In this context, it is also argued that multinational companies, through FDI, may also diffuse their knowledge of global markets to domestic firms and hence enable them to become more successful exporters. In short, FDI is assumed to be an important vehicle for the transfer of technological and business know-how. These knowledge transfers may have substantial spillover effects for the entire economy. Hence, through capital accumulation and knowledge spillovers, FDI may play an important role in economic growth

Apart from showing the importance of FDI on growth, the literature also realises that economic growth could be an important factor in attracting FDI flows. The important role of economic growth for attracting FDI is closely linked to the fact that FDI tends to be an important component of investing firms' strategic decisions (Ozturk 2007). In addition to the increase of capital formation of the recipient economy, FDI may also help growth by introducing new technologies, such as new production processes and techniques, managerial skills, ideas, and new varieties of capital goods. The growth rate of less developed countries is perceived to be highly dependent on the extent to which these countries can adopt and implement new technologies available in developed countries. By adapting new technologies and ideas (i.e. technological diffusion), they may catch up with the levels of technology in developing countries. It has been emphasized in the literature that the spillover effect can only be successful if certain characteristics can be found in the environment of the host country. These characteristics together determine the absorption capacity of technology spillovers of the host country (Blomström et al. 2000). Moreover, according to Blomström - Kokko (1998), spillover effects are most likely to be found in host countries, where the operations of foreign multinationals may influence local firms in the MNC's own industry as well as firms in other industries. Thus, FDI can only contribute to economic growth through spillovers when there is a sufficient absorptive capacity in the host country (Hermes - Lensink 2003).

One of the more important theoretical concepts defining the relationship between international capital flow in the form of FDI and economic growth is Dunning's theory of the investment-development path (IDP) (Dunning - Narula 1996). It explains decisions concerning FDI location by the different degrees of economic development of individual countries. Dunning notes interrelationships between an international investment position (net values of the investment per capita) and the economic development level measured by domestic product per capita (Dunning 1998). 
Moreover, the literature on growth theory also suggests that the FDI-economic growth relationships are not favourable. For example, Herzer et al. (2008) argue that if FDI crowds out domestic investment, then it is quite likely that the economic growth rate in the recipient country will decline (see also Güngór et al. 2014; Mickiewicz et al. 2004; Kosztowniak 2013).

According to Azeinman - Noy (2006), a positive impact of FDI on the economic growth rate depends on many factors, e.g. human capital, degree of the economy's openness, financial market development, or income per capita.

\section{RESULTS OF SELECTED EMPIRICAL ANALYSES OF THE FDI-ECONOMIC GROWTH RELATIONSHIP IN THE HOST COUNTRY}

In general, causality relations vary depending on the period studied, the countries studied, the treatment of variables (real or nominal), the econometric methods used, and the presence of other related variables, or the inclusion of interaction variables in the estimation equation. The results may be bi-directional, uni-directional, or there may be no causality relations.

Chowdhry - Mavrotas (2009) made an attempt to investigate the type of correlation (uni- or bi-directional) between FDI and GDP. They examined three countries, namely Chile, Malaysia, and Thailand in the period 1996-2000 using Granger's procedure. The results of their studies confirmed a uni-directional relationship in the case of Chile, with GDP attracting FDI, and a bi-directional correlation between FDI and GDP in the case of Malaysia and Thailand.

Herzer et al. (2008) investigated short- and long-term causality relationships between net FDI inflows and GDP, and the changes in real GDP in 28 countries of Latin America, Asia, and Africa in the period 1970-2003 using the Error Correction Model (ECM). Their studies indicate that it is not possible to define clearcut uni-directional relationships between the examined variables. Nevertheless, it is quite important how big the correlation between net FDI inflows and GDP in the host country is. If this correlation is low, then the effect of the investment on GDP is also poor. The forms of inflows - greenfields or brownfields - are also important. What is more, the FDI inflow effect can be observed exclusively in some sectors of the economy (e.g. industry).

Bi-directional interactions between FDI, production, and factors of production (total factor productivity, TFP) were also studied by Erricson - Irandoust (2001) for four OECD host countries (Denmark, Finland, Norway, and Sweden), with the use of the VAR model. As a result of using the new Granger procedure developed by Tod - Yamamoto (1995) and Yamada - Tod (1998), it was found that long-term correlations occur between FDI and production in Norway and 
Sweden. A bi-directional relationship in Granger's sense was discovered in Sweden, whereas a uni-directional type of FDI inflows contributes to the economic growth in Norway. No correlations were found in the case of Finland and Denmark. Investigations of a bi-directional relationship revealed two implications for economic policy. Firstly, that economic growth attracts inward FDI, secondly, that FDI is a key factor affecting economic growth.

Acaravci - Ozturk (2012) examined 10 European countries which underwent transformations, namely Bulgaria, Czech Republic, Estonia, Hungary, Latvia, Lithuania, Poland, Romania, Slovakia, and Slovenia in the years 1994-2008, using the Autoregression Model (ARDL). This study focused on an analysis of causality in Granger's sense between FDI, exports of goods and services, and GDP $(\%)$. The research results confirmed that only in four out of ten countries, i.e. the Czech Republic, Poland, Latvia, and Slovakia did both short- and long-term causality occur. Bi-directional relationships between GDP and exports were noted in Latvia and Slovakia, and between exports and FDI in Latvia. Other relationships were of a uni-directional nature. FDI inflows contributed to GDP growth in the Czech Republic and Slovakia. The GDP growth rate attracted FDI inflows in Latvia. Only in the case of Poland did the FDI inflow affect exports without affecting GDP. In the case of the remaining countries (Bulgaria, Estonia, Hungary, Lithuania, Romania, and Slovakia) no long-term dependencies were found among the three variables (see also Estrin 2014).

According to Javorcik (2004), the analysis based on firm-level data from Lithuania for the period 1996-2000 produces evidence consistent with positive productivity spillovers from FDI taking place through contacts between foreign affiliates and their local suppliers in upstream sectors. The spillover effects are associated with projects with shared domestic and foreign ownership, but not with fully owned foreign investments.

Moreover, the research conducted by Damijan et al. (2013) shows that FDI has significantly contributed to export restructuring in the Central Eastern European Countries (CEECs) in the period 1995-2007. However, the effects of FDI are heterogeneous across countries. While more advanced core CEECs succeeded in boosting exports in higher-end technology industries, non-core CEECs stuck with export specialisation in lower-end technology industries. This suggests that it is of key importance where FDI flows have been directed (Forte - Sarmento 2014).

Polish literature has studied the FDI effect on economic growth for many years, of which different aspects have been discussed, among others, the effect of FDI on the balance of payments, the transformation of economy (Kołodko 2000), modernisation of economy (Witkowska 2011), the increase in productivity, the transfer of knowledge, technology, know-how, and innovations (Karasze- 
wski 2004; Weresa 2009), competitiveness (Bieńkowski et. al. 2010), institutions and economic policy (Wojtyna 2008), and other key areas determining economic growth.

Nevertheless, investigations concerning mutual relationships between FDI and GDP have been carried out by very few authors, including, among others, Gurgul - Lach (2009), who covered Poland in the years 2000-2008 with the use of Granger tests, and VAR and VECM models. These investigations confirmed the existence of a bi-directional relationship between FDI and GDP; however, they did not define the impact strength or explanation degree between these variables. More foreign investment exerts a vital effect on the GDP value in Poland and GDP is a significant factor attracting foreign investors. The cited authors also noted mutual relationships between FDI and inflation as well as FDI and the openness of economy (which was assumed to be the ratio of imports and exports to total GDP). It was also found that there is a uni-directional causality between FDI and exchange rate as well as exports.

Misztal (2012) studied the effect of FDI, gross fixed capital formation, labour force resources, and exports on economic growth in Poland in the years 2000-2009 using the VECM model. His research, however, focuses on the unidirectional effect of the above-mentioned factors of production on GDP. On the basis of the VECM model estimates, it was found that FDI was one of the factors which significantly determined the GDP growth rate in Poland in the years 2000-2009. On the other hand, it was also discovered that among all analysed factors, the changes in employment figures had the biggest impact on GDP dynamics. A favourable and vital influence of FDI on GDP dynamics in Poland was also confirmed, but considering the remaining factors determining economic growth, this factor turned out to be the least significant determinant of economic growth in Poland.

Marona - Bieniek (2013) also examined the uni-directional effect of FDI on GDP, exports, imports, R\&D expenditure, and the unemployment rate in Poland in the period 1996-2010, concentrating on the so-called FDI impulse response functions. Their research indicates that the strongest FDI effect is observed in the initial periods, although the FDI effect is also of a long-term character. The strongest response regards imports, exports as well as unemployment rate. A weaker effect occurs in the case of R\&D expenditure and GDP. 


\section{CONCEPTUAL FRAMEWORK}

\subsection{Model approach to production function - the scope and method of the study}

Our Cobb-Douglas type function encompasses four types of inputs: domestic capital (K), labour (L), foreign capital (F), and expenditure on information and telecommunication technologies (ICT):

$$
Y_{i t}=A_{i t} e^{c t}\left(K_{i t}\right)^{\alpha}\left(L_{i t}\right)^{\beta}\left(F_{i t}\right)^{\gamma}\left(I C T_{i t}\right)^{\delta} e^{u_{i t}}
$$

where $Y$ is GDP in the $i$-th country, $A$ is the technological progress coefficient, $K$ is the domestic capital input, $L$ is the labour input, $F$ is the foreign capital input, while $K$ and $F$ refer to non-ICT capital, $I C T$ is expenditure on information and communication technologies, $\alpha, \beta, \gamma, \delta$ are production elastitcity coefficients in relation to domestic capital input, labour force, foreign capital, and ICT with respect to output, $e$ and $c$ are constant parameters, $u_{i t}$ is the mean error of an estimate, and $t$ is the period (Dimelis - Papaioannou 2010: 83).

In order to analyse the relationship between the changes in GDP values and the factors of production in Poland in the years 1992-2012, broken down by domestic capital and foreign capital, the formula for the production function is as follows:

$$
G D P_{t}=f\left(G F C F_{t}, \text { Employ }_{t}, F D I_{t}, \text { Exports }_{t}, R \& D_{t}\right)
$$

where: GDP is the Gross Domestic Product, GDP (in USD, at fixed prices of 2005), GFCF is the Gross Fixed Capital Formation (in million USD), Employ is total employment in economy (number of people), $F D I$ is foreign direct investment (in million USD), Exports is the value of exports of goods and services (in million USD), and $R \& D$ is the domestic gross expenditure on $\mathrm{R} \& \mathrm{D}$ (in million USD, at fixed prices of 2005, PPPs).

Prior to the estimation of the production function model for Poland, the variable values were logarithmed to "smooth them up". The original annual data for 1992-2012 were taken from the OECD's public database. The adoption of the above-mentioned explanatory variables for GDP results from the make-up of the Cobb-Douglas component functions and research methodology adopted by many authors, among others, by Dimelis - Papoioannou (2010), Roman - Padureanu (2012), and Driffield - Jindra (2012), who analysed the FDI effect on economic growth in host countries. 


\subsection{Characteristics of the model's sequences of variables}

The analysis of the logarithmed values of the dependent variable GDP and the explanatory variables indicates that recession was strongly marked in the periods 2001-2003 and 2008-2010. The variables particularly sensitive to changes were those of FDI inflows, employment, and gross domestic expenditure on R\&D, which is confirmed by the considerable deviations of those variables over time.

A preliminary analysis of time series graphs leads to the conclusion that we are dealing with a pronounced non-stationary process in the case of changes in GDP and exports: in these cases, the values of the series clearly grow over time (Figure 1). The absolute value of the Pearson correlation coefficients confirmed statistically significant correlations among the variables.

To verify the stationarity of the analysed time series, the Augmented DickeyFuller (ADF) test was used, estimated with the use of the regression equation in the following form (Welfe 2003):

$$
\Delta_{y t}=\mu+\delta_{t-1}+\sum_{i=1}^{k} \delta_{i} \Delta y_{t-1}+\epsilon_{t}
$$
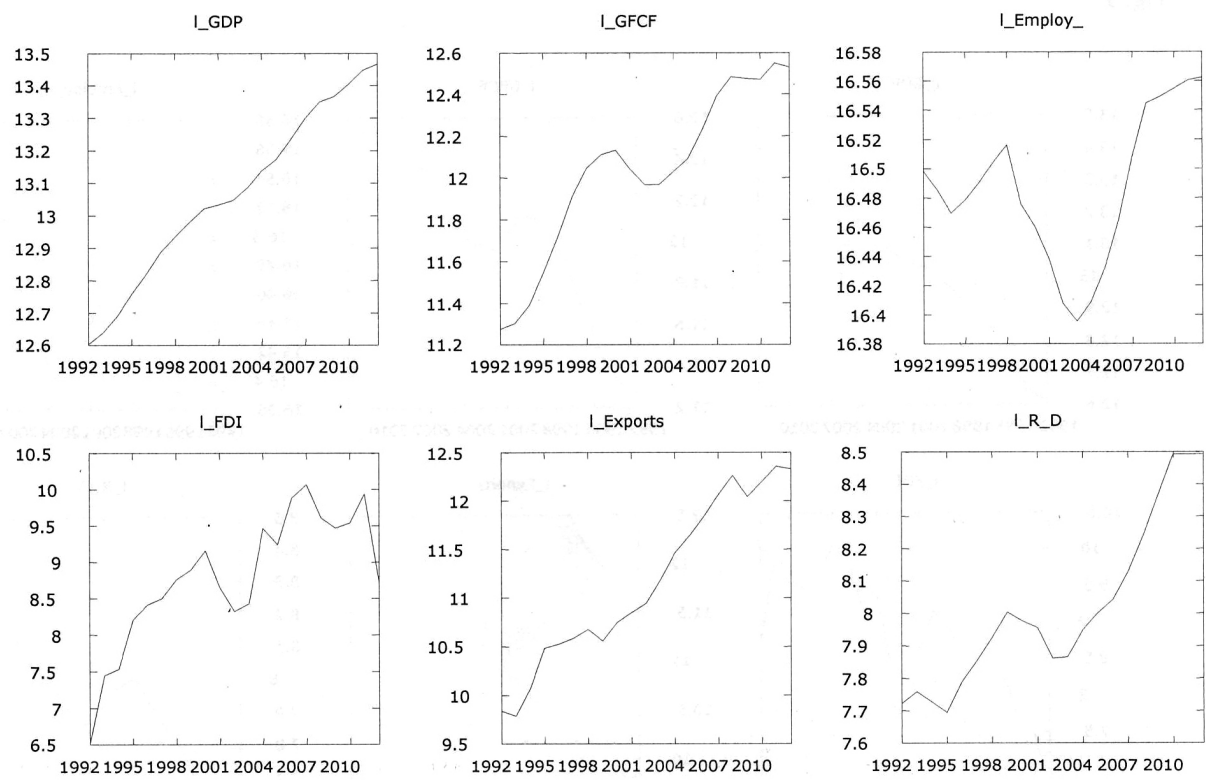

Figure 1. Time series of the model variables for Poland, 1992-2012

(annual data, logarithmed)

Source: Author's compilation based on OECD StatExtracts (2014), with the use of the Gretl 1.9.14 program. 
The value of the test statistic was calculated with the use of the formula:

$$
A D F=\frac{\widehat{\delta}}{s_{\widehat{\delta}}}
$$

where $\widehat{\delta}$ means the parameter evaluation, and $s_{\widehat{\delta}}$ is the parameter estimate error.

For all analysed variables it was found that they lacked stationarity of time series, but a unit root $\mathrm{a}=1$ occurred at process I(1). For each sequence separately the ADF test was carried out with an absolute term and with an absolute term and a linear trend, with the number of lags equal: 3 for the process (GDP), 4 for the process (GFCF, Employment), 5 for the process (R\&D), 6 for the process (Exports), 7 for the process (FDI), in relation to max. 8 for the process. The test results confirm non-stationarity. Assuming that the null hypothesis is true, empirical significance levels ( $p$-values of the tests) prove that the probability of obtaining ADF test statistics is high for the majority of variables. Thus, there are no reasons for rejecting hypotheses that the examined sequences are non-stationary. Some doubts appeared only in the case of gross fixed capital formation, at ADF with an absolute term and a linear trend where the p-value was low (Table 1).

Table 1. Stationarity test results on the basis of the ADF test for the GDP process, GFCF, employment, FDI, exports, and expenditure on R\&D

\begin{tabular}{lcccccc}
\hline Specification & GDP & GFCF & Employment & FDI & Exports & R\&D \\
\hline $\begin{array}{l}\text { Null hypothesis: } \\
\text { unit root } \\
\text { appears }\end{array}$ & $\begin{array}{c}\mathrm{a}=1 ; \\
\text { process I(1) }\end{array}$ & $\begin{array}{c}\mathrm{a}=1 ; \\
\text { process I(1) }\end{array}$ & $\begin{array}{c}\mathrm{a}=1 ; \\
\text { process I(1) }\end{array}$ & $\begin{array}{c}\mathrm{a}=1 ; \\
\text { process I(1) }\end{array}$ & $\begin{array}{c}\mathrm{a}=1 ; \\
\text { process I(1) }\end{array}$ & $\mathrm{a}=1 ;$ \\
\hline $\begin{array}{l}\text { ADF test } \\
\text { with absolute } \\
\text { term(const); }\end{array}$ & $\mathrm{p}=0.759$ & $\mathrm{p}=0.6927$ & $\mathrm{p}=0.7396$ & $\mathrm{p}=0.8491$ & $\mathrm{p}=0.9691 \mathrm{p}=0.98416$ \\
$\begin{array}{l}\text { Asymptotic } \\
\text { p-value }\end{array}$ & & & & & & \\
\hline $\begin{array}{l}\text { ADF test } \\
\text { with absolute } \\
\text { term(const) } \\
\text { and linear trend; } \\
\begin{array}{l}\text { Asymptotic } \\
\mathrm{p} \text {-value }\end{array}\end{array}$ & $\mathrm{p}=0.1579$ & $\mathrm{p}=0.002506$ & $\mathrm{p}=0.973$ & $\mathrm{p}=0.8006$ & $\mathrm{p}=0.4932$ & $\mathrm{p}=0.3244$ \\
\hline
\end{tabular}

Source: Author's compilation based on OECD StatExtracts (2014), with the use of the Gretl 1.9.14 program.

To verify the conclusions drawn on the basis of the ADF test, the KPSS (Kwiatkowski-Philips-Schmidt-Shin) stationarity test was carried out, where the null hypothesis assumes a sequence stationarity, whereas the alternative hypothesis assumes the occurrence of the unit root. The initial test model can take the following form: 


$$
\gamma \mathrm{t}=\beta \mathrm{t}+r_{t}+\xi_{t}
$$

where: $r_{t}=r_{t}-1+u_{t}$, where $\xi_{t}$ and $u_{t}$ are a stationary and a white-noise random component, respectively. On the other hand, the KPSS test statistic is calculated with the use of the formula:

$$
K P S S=T^{-2} \sum_{t=1}^{T}\left(\sum_{i=1}^{t} e_{i}\right) / \hat{\sigma}^{2}
$$

where $e_{i}$ denotes residuals, and $\widehat{\sigma}^{2}$ is a long-term variance estimator (Welfe 2003).

The variables were analysed assuming the maximum number of lags of 2. In most cases, the test statistic values for the KPSS test without a trend were higher than critical values of the test; in the case of the KPSS test with a trend, the test statistic values were mostly lower than the critical value for the test at both significance levels of 0.10 and 0.05 (Table 2).

Next, the Johansen test was carried out, which confirmed co-integration among examined variables. In the Johansen test, all eigenvalues are significantly different from zero, which means that all variables are stationary.

The next step was to determine the maximum lag order for the VAR model. According to the AIC, FDI and HQC information criteria, the maximum lag equals 2 .

To analyse the VAR model stability, the unit root test was carried out (Kufel 2011). It revealed that in the analysed model, all roots of the equations as regards the module are lower than 1, which is illustrated in Figure 2.

\begin{tabular}{|c|c|c|c|c|c|c|c|}
\hline \multicolumn{2}{|c|}{ Specification } & \multirow{2}{*}{$\begin{array}{c}\text { GDP } \\
0.794052\end{array}$} & \multirow{2}{*}{$\begin{array}{c}\text { GFCF } \\
0.712985\end{array}$} & \multirow{2}{*}{$\begin{array}{c}\text { Employment } \\
0.240634\end{array}$} & \multirow{2}{*}{$\begin{array}{c}\text { FDI } \\
0.643346\end{array}$} & \multirow{2}{*}{$\begin{array}{l}\text { Exports } \\
0.78499\end{array}$} & \multirow{2}{*}{$\begin{array}{c}\mathrm{R} \& \mathrm{D} \\
0.687599\end{array}$} \\
\hline $\bar{\Xi}$ & Test statistic & & & & & & \\
\hline $\begin{array}{l}n \pi \\
\hat{n} \\
\underline{1}\end{array}$ & $\begin{array}{l}\text { Critical value } \\
\text { of the test }\end{array}$ & \multicolumn{6}{|c|}{0.357 (for $10 \%) ; 0.483$ (for $5 \%$ ); 0.697 (for $1 \%$ ) } \\
\hline \multirow{2}{*}{ 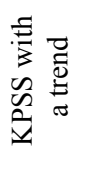 } & Test statistic & 0.101718 & 0.0993745 & 0.162945 & 0.124097 & 0.0736774 & 0.14291 \\
\hline & $\begin{array}{l}\text { Critical value } \\
\text { of the test }\end{array}$ & \multicolumn{6}{|c|}{0.124 (for $10 \%) ; 0.150($ for $5 \%) ; 0.207$ (for $1 \%$ ) } \\
\hline
\end{tabular}

Table 2. KPSS stationarity test results for the examined sequences

Source: Author's compilation based on OECD StatExtracts (2014) with the use of the Gretl 1.9.14 program. 


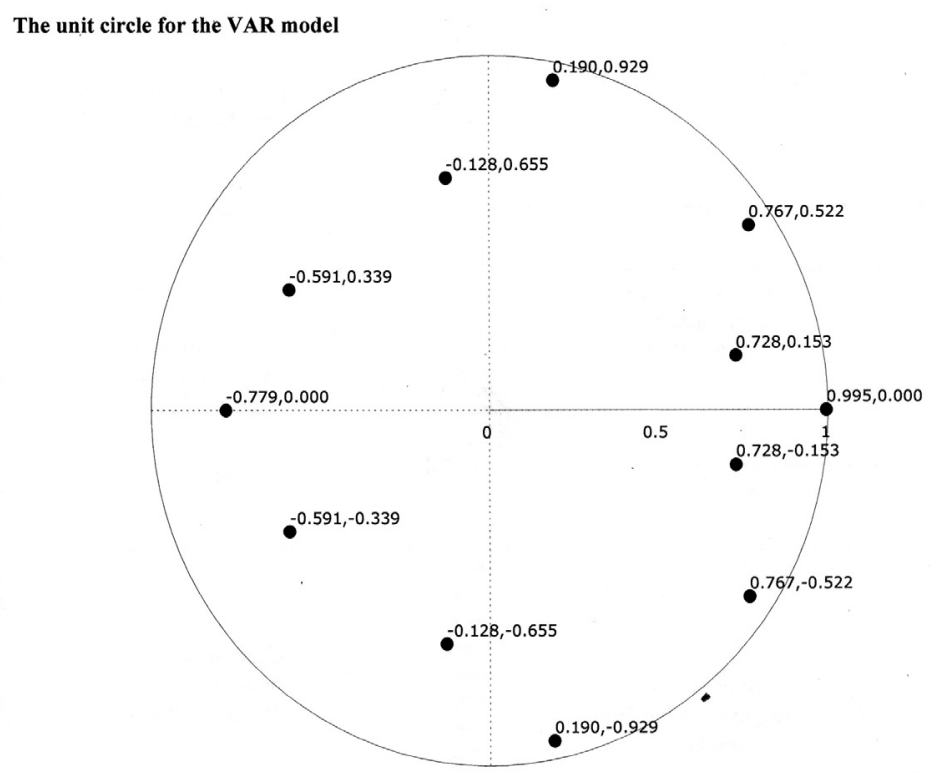

Figure 2. The unit circle for the VAR model

Source: Author's compilation with the use of the Gretl 1.9.14 program.

Since the roots of the characteristic equation are inside the unit circle (they are lower than 1), it is possible to supplement the VAR model with the so-called component of error correction expressing the long-term relationship, and the interpretation of impulse responses and variance decomposition will give credible results. Besides, in accordance with the Granger representation theorem, if variables $y_{t}$ and $x_{t}$ are integrated of order one I(1) and are co-integrated, the relationship between them can be represented as the Vector Error Correction Model (VECM) (Górecki 2010).

The general formula for VECM is presented below (Kusideł 2010):

$$
\Delta x_{t}=\Psi_{0} D_{t}+\sum_{i=1}^{k-1} \prod_{i} \Delta x_{t-1}+\prod x_{t-k}+\epsilon_{t}
$$

where:

$$
\begin{aligned}
& \prod=\sum_{i=1}^{k} A_{i}-l ; \\
& \prod_{i}=\sum_{j=1}^{k} A_{j}-l ; \\
& x_{1} t=\left[\begin{array}{llll}
x_{1} 1 t & x_{1} 2 t & \ldots & x_{1}(n t)
\end{array}\right] \text {. }
\end{aligned}
$$




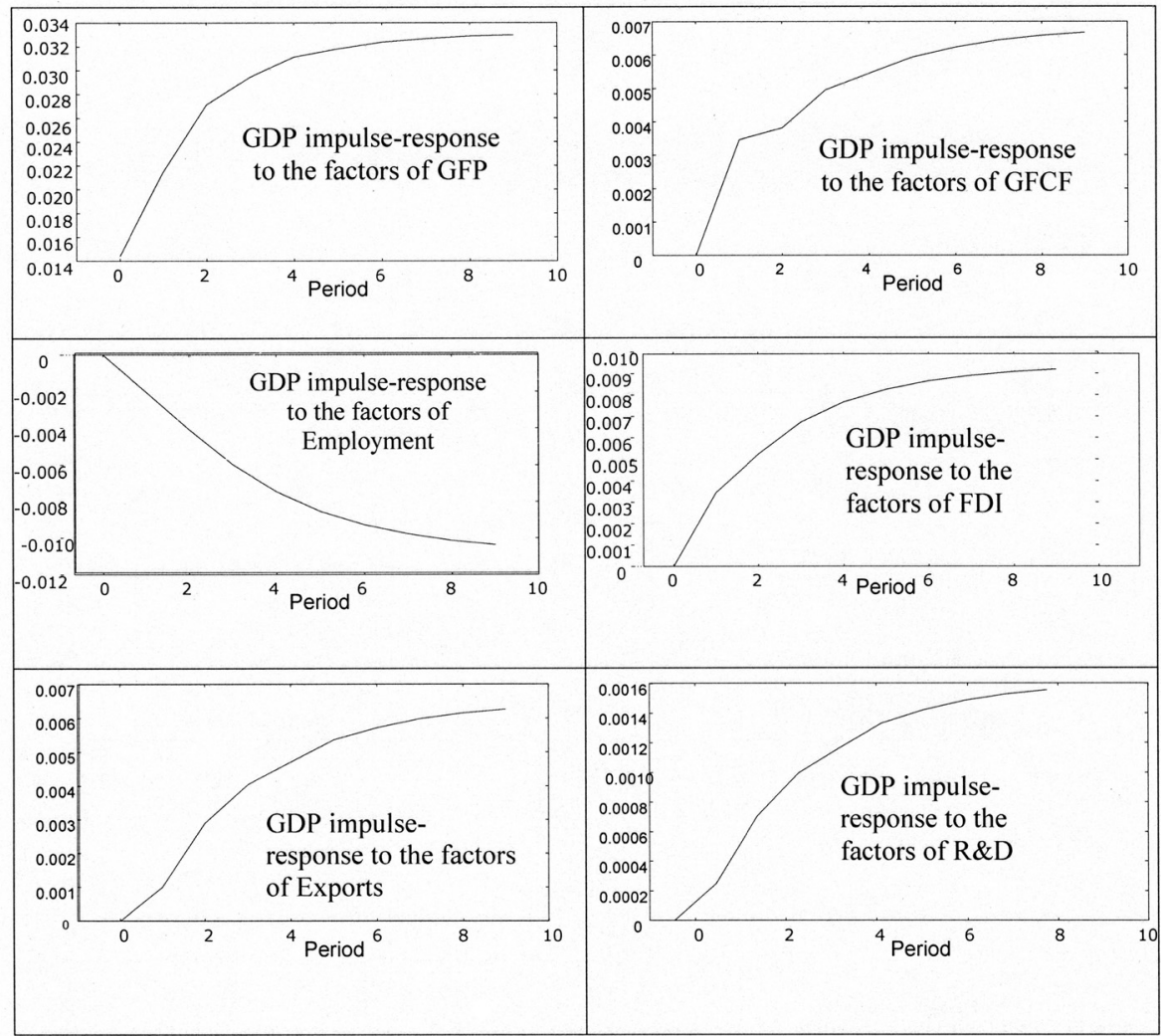

Figure 3. Graphs of impulse responses of GDP in Poland

Source: Author's own compilation based on OECD StatExtracts (2014), with the use of the Gretl 1.9.14 program.

In the VECM, the dependent variable increment $Y_{t}$ depends not only on the independent variable increment $X_{p}$ but partially also on the error magnitude by which $Y_{t-1}$ deviates from the long-term balance (Górecki 2010).

The VECM model was used to analyse the factors determining changes in the GDP value in Poland in the years 1992-2012 and to examine long-term dependencies and the cause-and-effect relationships occurring among the variables. In this model, the lag order equal 2 was adopted and co-integration order $=1$. Appendix 1 presents the results of the estimated VECM structural parameter model.

Next, the VECM model was analysed in the autocorrelation tests, the ARCH effect test, and the test for the residual decomposition normality. The model passed all the tests successfully, which means that the study of impulse responses was possible. Particular attention was given to the examination of: (1) GDP and FDI impulse-response function as well as (2) verification whether there are cause- 
and-effect relationships between GDP and FDI, i.e. whether GDP attracts FDI inflows and whether the investment contributes to GDP growth.

The analysis of the GDP impulse-response function to the factors of production in Poland in the years 1992-2012 indicates that, over time, impulses (stimuli, shocks, or the so-called innovations) of the five examined factors exerted mostly a favourable and growing effect on future GDP values, which is testified to by changes in the GDP sensitivity coefficients and graphs of impulse-response functions (Figure 3).

In the first year after the shock, the strongest GDP response was noted for changes in FDI and exports, the GDP sensitivity coefficient to FDI changes in Poland stood at $37.2 \%$, growing to $37.9 \%$ ten years later. The GDP sensitivity to unit changes in exports stood at $9.6 \%$ after one year and then, over time, it clearly weakened to reach only $2.4 \%$ ten years later. Positive impulses with growing significance for GDP were observed from the gross fixed capital formation: from $5.5 \%$ after one year, to grow stepwise up to $10.2 \%$ after the second year, and up to $17 \%$ ten years later. The GDP sensitivity coefficient to changes in employment in Poland stood at $1.1 \%$ after one year and grew further to $2.1 \%$ after two years, to gradually reach the max. value of $3 \%$ after ten years. The weakest positive response of GDP occurred to the impulse from the gross domestic expenditure on $\mathrm{R} \& \mathrm{D}$ : in the first year after the shock it stood at $0.7 \%$, growing to $7.2 \%$ after 5 years, and to $7.6 \%$ after 10 years.

All examined growth factors together positively affected GDP sensitivity with greater force over time. The coefficients of GDP sensitivity to impulses indicate that changes (shocks) in GDP over time have a growing effect on future GDP values. GDP sensitivity was growing from $1.4 \%$ after the first year to $3.1 \%$ after five years, and eventually to $3.3 \%$ after ten years (Table 3 ).

Table 3. GDP responses to impulses in the form of unit changes in GDP, GFCF, employment, FDI, exports, and gross domestic expenditure on $\mathrm{R} \& \mathrm{D}$

\begin{tabular}{lclcccc}
\hline Period & 1_GDP & 1_GFCF & 1_Employment & 1_FDI & 1_Exports & 1_R\&D \\
\hline 1 & 0.014400 & 0.054540 & 0.010513 & 0.37249 & 0.096407 & 0.0070821 \\
\hline 2 & 0.021428 & 0.10246 & 0.021106 & 0.35482 & 0.095397 & 0.026724 \\
\hline 3 & 0.027121 & 0.13507 & 0.025632 & 0.36030 & 0.060750 & 0.049488 \\
\hline 4 & 0.029427 & 0.15125 & 0.028330 & 0.36485 & 0.031885 & 0.067355 \\
\hline 5 & 0.031115 & 0.15936 & 0.029021 & 0.36564 & 0.029066 & 0.072046 \\
\hline 6 & 0.031825 & 0.16357 & 0.029494 & 0.37345 & 0.028309 & 0.073300 \\
\hline 8 & 0.032367 & 0.16660 & 0.029722 & 0.37508 & 0.026096 & 0.074819 \\
\hline 9 & 0.032672 & 0.16830 & 0.029831 & 0.37700 & 0.024980 & 0.075620 \\
\hline 10 & 0.032868 & 0.16934 & 0.029873 & 0.37819 & 0.024620 & 0.075955 \\
\hline
\end{tabular}

Source: Author's compilation based on OECD StatExtracts (2014), with the use of the Gretl 1.9.14. program. 


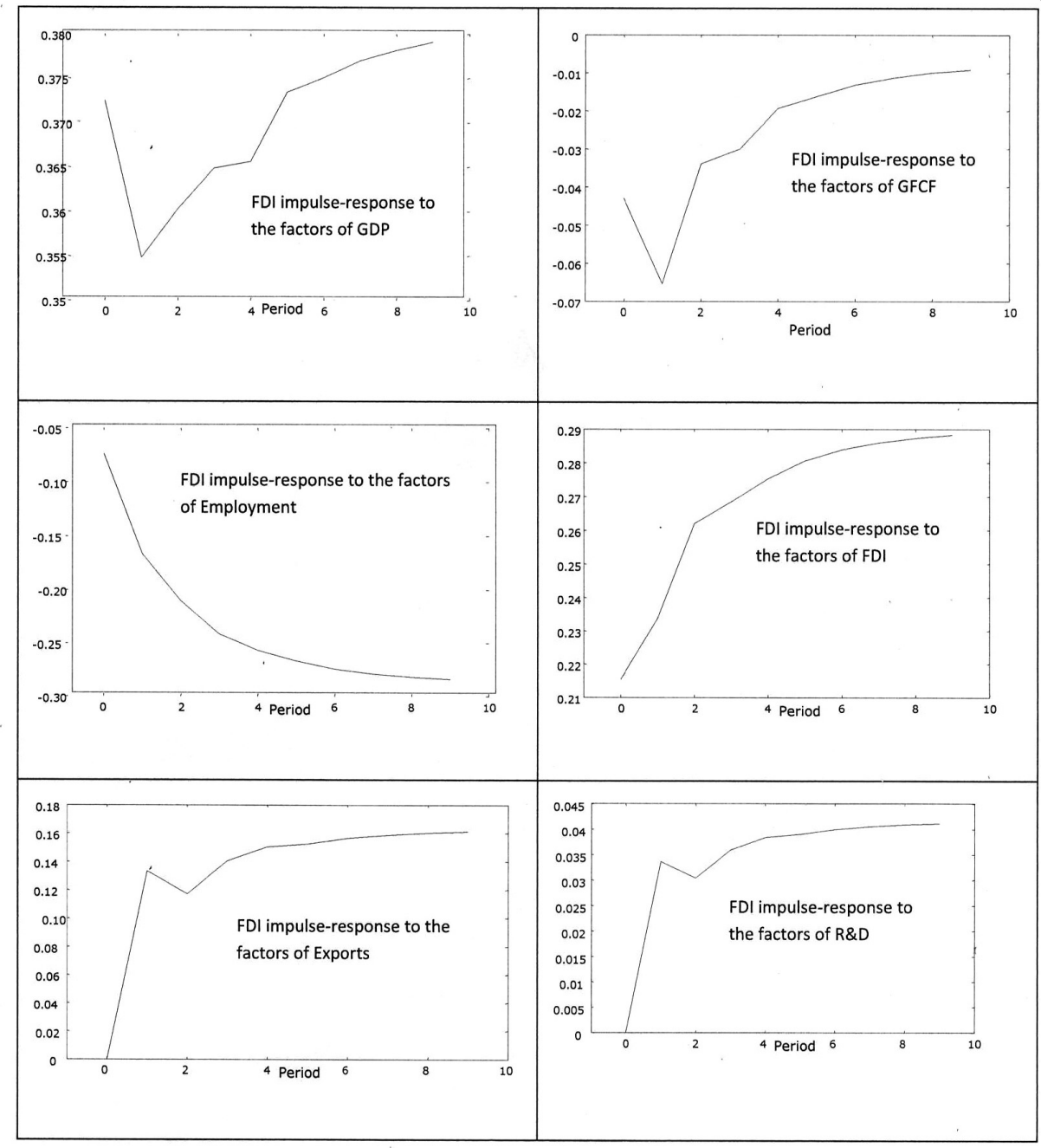

Figure 4. Graphs of FDI impulse responses in Poland, the VECM model

Source: Author's compilation based on OECD StatExtracts (2014), with the use of the Gretl 1.9.14. program.

On the other hand, the graphs of the response-impulse functions of FDI to growth factors in the years 1992-2012 also indicate that, over time, the impulses of the five examined factors exerted mostly a positive and growing impact on future FDI values. A significant change in FDI sensitivity to the majority of the examined factors was noticeable in the first and the second year after the occurrence of the impulse, the so-called shock (innovation). The graphs of the function 
clearly indicate that changes in GDP, GFCF, FDI, exports, and R\&D revealed fairly significant changes in the impact strength with regard to FDI in the second year in comparison to the first one, which was marked by a characteristic "step" in the graph (Figure 4).

An analysis of FDI sensitivity indicates that in the first year after the shock, it responded only to the impulse from FDI itself, exports, and gross domestic expenditure on R\&D. The strongest positive impact on changes in future FDI was exerted by changes in current FDI. The FDI sensitivity coefficient stood at $21.5 \%$ after the first year, to grow to $28.8 \%$ after the tenth year. The FDI response to the impulse of changes in exports was $1.3 \%$ after the first year, grew to $4.1 \%$ after the third year, and falling in subsequent years to reach $3.03 \%$ after the $10^{\text {th }}$ year. The impact of gross domestic expenditure on R\&D on FDI sensitivity was only $0.7 \%$ after the first year and $0.4 \%$ after the $10^{\text {th }}$ year. The FDI responses to impulses from gross fixed capital formation equalled only $1.3 \%$ after the second year, but grew to $4.5 \%$ after the tenth year. A low value of FDI sensitivity was noted for GDP, as it was only $0.3 \%$ after the second year and revealed a tendency for a slight growth to $0.9 \%$ after the $10^{\text {th }}$ year.

The weakest and, what is more, a negative impact on the FDI sensitivity was observed from employment: it stood at $-0.86 \%$ after the first year and reached $-0.38 \%$ after the $10^{\text {th }}$ year. These results prove that FDI inflows to the host country slowed down despite improvement in the labour market situation (Table 4).

Decomposition of the residual variance (residual component analysis, RCA) was carried out to define the degree of explanation of the changes in GDP and FDI by changes in the factors of production in Poland in the years 1992-2012. Ten periods were the forecast horizon adopted for the decomposition purposes.

Table 4. FDI responses to impulses in the form of unit changes in GDP, GFCF, FDI, employment exports and gross domestic expenditure on $\mathrm{R} \& \mathrm{D}$

\begin{tabular}{cllcccc} 
Period & 1_GDP & 1_GFCF & 1_Employment & 1_FDI & 1_Exports & 1_R\&D \\
\hline 1 & 0.0000 & 0.0000 & 0.0000 & 0.21539 & 0.013146 & 0.0073950 \\
\hline 2 & 0.0034435 & 0.013440 & -0.00086011 & 0.23376 & 0.038416 & $4.0552 \mathrm{e}-005$ \\
\hline 3 & 0.0052394 & 0.023776 & -0.00062379 & 0.26204 & 0.041117 & -0.0020548 \\
\hline 4 & 0.0067241 & 0.032192 & -0.00041099 & 0.26854 & 0.033245 & 0.0017938 \\
\hline 5 & 0.0076519 & 0.036961 & -0.00040535 & 0.27530 & 0.031558 & 0.0031169 \\
\hline 6 & 0.0082395 & 0.039974 & -0.00041122 & 0.28062 & 0.031636 & 0.0033244 \\
\hline 7 & 0.0086332 & 0.042066 & -0.00039856 & 0.28395 & 0.031187 & 0.0036233 \\
\hline 8 & 0.0088970 & 0.043469 & -0.00038964 & 0.28600 & 0.030708 & 0.0039215 \\
\hline 9 & 0.0090709 & 0.044381 & -0.00038732 & 0.28740 & 0.030481 & 0.0040874 \\
\hline 10 & 0.0091852 & 0.044981 & -0.00038594 & 0.28835 & 0.030357 & 0.0041811 \\
\hline
\end{tabular}

Source: Author's compilation based on OECD (StatExtracts 2014), with the use of the Gretl 1.9.14. 
The error variance decomposition calculations for the variable GDP show that it was explained by GFCF, FDI, and employment to the largest extent, both in the second and the tenth year of the forecast. Changes in GFCF accounted for $1.72 \%$ of GDP changes. This indicator grew to $2.79 \%$ in the tenth year of the forecast. Almost a 5.0\% increase in the degree of GDP explanation over the period of a 10 -year forecast is attributable to employment, namely from $0.59 \%$ to $5.67 \%$. This fairly significant increase in the explanation degree testifies to a growing "efficiency" of the impact of employment on GDP in the long-time perspective. The group of long-term impact factors includes also FDI. In the second-year of the forecast, FDI changes accounted for $1.70 \%$ of GDP, growing to $5.22 \%$ in the tenth year, reaching almost the same value as the one for the employment impact. On the other hand, the lowest degree of explanation of the changes in GDP was noted for the gross domestic expenditure on R\&D $(0.008 \%$ and $0.134 \%)$. Changes in exports accounted for GDP changes in $c a .0 .144 \%$ in the second year of the forecast, growing to $2.18 \%$ in the tenth year.

Recapitulating, in the short- and long-term perspective, the pillars of explanation of changes in GDP are three factors, namely changes in GFCF, FDI, and employment; however, over time, the growing tendency is revealed by employment (Table 5).

On the other hand, a decomposition analysis of FDI changes shows that the factor providing the highest degree of their explanation was changes in the recipient country's GDP. The significance of this factor is immense because as much as $72.09 \%$ of FDI changes were explained by GDP in the first year of the forecast. Despite the fact that, over time, the significance of GDP for FDI lowers to $47.22 \%$ in the tenth year, it still remains the most important explanation factor.

Table 5. Variance decomposition for the variable: GDP

\begin{tabular}{cccccccc}
\hline Period & \multirow{2}{*}{ Stand. error } & 1_GDP & 1_GFCF & 1_Employment & L_FDI & 1_Exports & 1_R\&D \\
\hline 1 & 0.0143996 & 100.0000 & 0.0000 & 0.0000 & 0.0000 & 0.0000 & 0.0000 \\
\hline 2 & 0.0263726 & 95.8268 & 1.7237 & 0.5910 & 1.7049 & 0.1447 & 0.0088 \\
\hline 3 & 0.0387132 & 93.5478 & 1.7709 & 1.3916 & 2.6229 & 0.6296 & 0.0373 \\
\hline 4 & 0.0498744 & 91.1760 & 2.0511 & 2.2766 & 3.3980 & 1.0359 & 0.0624 \\
\hline 5 & 0.0601897 & 89.3253 & 2.2259 & 3.0957 & 3.9493 & 1.3234 & 0.0804 \\
\hline 6 & 0.0695864 & 87.7468 & 2.3913 & 3.8231 & 4.3567 & 1.5854 & 0.0967 \\
\hline 7 & 0.0782554 & 86.4902 & 2.5246 & 4.4252 & 4.6620 & 1.7887 & 0.1094 \\
\hline 8 & 0.0862880 & 85.4738 & 2.6340 & 4.9233 & 4.8975 & 1.9518 & 0.1196 \\
\hline 9 & 0.0937773 & 84.6510 & 2.7230 & 5.3335 & 5.0821 & 2.0826 & 0.1278 \\
10 & 0.1007980 & 83.9793 & 2.7961 & 5.6719 & 5.2292 & 2.1891 & 0.1344 \\
\hline
\end{tabular}

Source: Author's compilation based on OECD StatExtracts (2014), with the use of the Gretl 1.9.14. program. 
Table 6. Variance decomposition for the variable: FDI

\begin{tabular}{rccccccc}
\hline Period & $\begin{array}{c}\text { Stand. } \\
\text { error }\end{array}$ & 1_GDP & 1_GFCF & 1_Employment & 1_FDI & 1_Exports & 1_R\&D \\
\hline 1 & 0.438679 & 72.0994 & 0.9592 & 2.8328 & 24.1086 & 0.0000 & 0.0000 \\
\hline 2 & 0.65114 & 62.4189 & 1.4433 & 7.8495 & 23.8311 & 4.1900 & 0.2672 \\
\hline 3 & 0.826187 & 57.7897 & 1.0645 & 11.3688 & 24.8618 & 4.6137 & 0.3016 \\
\hline 4 & 0.98384 & 54.5056 & 0.8441 & 14.0315 & 24.9824 & 5.2899 & 0.3464 \\
\hline 5 & 1.12594 & 52.1620 & 0.6740 & 15.9104 & 25.0529 & 5.8200 & 0.3807 \\
\hline 6 & 1.25781 & 50.6126 & 0.5567 & 17.2434 & 25.0524 & 6.1338 & 0.4011 \\
\hline 7 & 1.38018 & 49.4213 & 0.4714 & 18.2710 & 25.0398 & 6.3794 & 0.4171 \\
\hline 8 & 1.49451 & 48.5121 & 0.4078 & 19.0662 & 25.0173 & 6.5674 & 0.4293 \\
\hline 9 & 1.60191 & 47.7987 & 0.3588 & 19.6937 & 24.9939 & 6.7160 & 0.4388 \\
\hline 10 & 1.70333 & 47.2297 & 0.3203 & 20.1977 & 24.9717 & 6.8341 & 0.4465 \\
\hline
\end{tabular}

Source: Author's compilation based on OECD StatExtracts (2014), with the use of the Gretl 1.9.14. program.

Over time, the FDI changes exerted a fairly stable impact on future FDI values, fluctuating around $24-25 \%$. Changes in employment accounted for $2.83 \%$ of the GDP changes in the first year, growing most in the second-to-fourth year, and reaching the value of $20.19 \%$ in the tenth year.

The impact of changes in exports on the explanation degree of FDI was noticeable from the second year (4.19\%) and it grew to $6.83 \%$ in the tenth year. The lower degree of change explanation was noted for GFCF and it revealed a falling trend (from $0.95 \%$ in the first year of forecast to $0.32 \%$ in the tenth year). Gross domestic expenditure on R\&D accounted for FDI changes to the least extent, although, over time, the impulse had a growing effect (from $0.26 \%$ in the second year to $0.44 \%$ in the tenth year) (Table 6).

\section{CHANGES IN THE STRUCTURE OF FDI INFLOWS}

The structure of FDI inflows indicates a rather unfavourable tendency of financing foreign investment by other capital (including, e.g., debt securities, commercial credits) ${ }^{1}$. On average, the ratio of other capital to the total value of FDI inflows hovered around 30\%; however, following the 2007/2008 financial crisis, it rose to almost $41 \%$ in $2008,49 \%$ in 2011 , and nearly $62 \%$ in 2012 . In the years 1999-2003 and 2008, foreign investors transferred their profits abroad, hence the occurrence of the so-called negative re-investment. In 2012, capital contributions

FDI is the sum of equity capital, reinvestment earnings, other capital. Among other capital we take credit, loans and debt securities into account as well (NBP 2014). 
Table 7. Inflow of FDI to Poland, 1999-2012 (million EUR)

\begin{tabular}{lcccrc}
\hline Year & $\begin{array}{c}\text { Capital contributions } \\
\text { (equity securities, shares, } \\
\text { contributions-in-kind) }\end{array}$ & $\begin{array}{c}\text { Reinvested } \\
\text { profits }\end{array}$ & $\begin{array}{c}\text { Other capital } \\
\text { (debt securities, } \\
\text { credit including } \\
\text { commercial } \\
\text { credits) }\end{array}$ & $\begin{array}{c}\text { Total } \\
\text { FDI } \\
\text { inflows }\end{array}$ & $\begin{array}{c}\text { Ratio of other } \\
\text { capital to total } \\
\text { FDI inflows } \\
\text { value } \\
\text { (\%) }\end{array}$ \\
\hline 1999 & 5089 & -425 & 2160 & 6824 & 31.65 \\
\hline 2000 & 9409 & -433 & 1358 & 10334 & 13.14 \\
\hline 2001 & 5585 & -1161 & 1948 & 6372 & 30.57 \\
\hline 2002 & 4115 & -1298 & 1554 & 4371 & 35.55 \\
\hline 2003 & 3029 & -74 & 1358 & 4313 & 31.49 \\
\hline 2004 & 5841 & 5085 & -943 & 9983 & -9.45 \\
\hline 2005 & 3555 & 2709 & 2016 & 8280 & 24.35 \\
\hline 2006 & 5632 & 4358 & 5071 & 15061 & 33.67 \\
\hline 2007 & 5613 & 6782 & 4847 & 17242 & 28.11 \\
\hline 2008 & 6698 & -713 & 4143 & 10128 & 40.91 \\
\hline 2009 & 3799 & 3852 & 1962 & 9343 & 21.00 \\
\hline 2010 & 3181 & 5627 & 1699 & 10507 & 16.17 \\
\hline 2011 & 2424 & 5177 & 7232 & 14832 & 48.76 \\
\hline 2012 & -2637 & 4440 & 2913 & 4716 & 61.77 \\
\hline
\end{tabular}

Source: Author's compilation based on National Bank of Poland (NBP) data (2008-2012).

to the amount of EUR 2.6 billion were withdrawn, while other capital, i.e. different debt securities to the amount of EUR 2.9 billion flowed in. In comparison to 2011, in 2012 the value of inflows dropped by EUR 10.1 billion, i.e. by $68 \%$. The biggest drops were noted in the inflow of capital contributions and other capital. However, it is also quite common in other net FDI receiving countries that capital is "retracted" by multinational companies during crisis periods, using various channels (not reinvesting but repatriating, affiliates giving credits to parents, even outward FDI, etc.) (Table 7).

An analysis of the structure of FDI inflows indicates that the value of equity was either partly withdrawn or considerably reduced. This tendency is unfavourable for the long-term prospects of Polish economy growth because foreign investment was clearly reduced in some key branches. What is more, the value of reinvested profits indicated big changes, and in 2010, it was clearly reduced. In the years 2011-2012, the building industry noted negative re-investment. The total loss exceeded the amount of re-invested profits. ${ }^{2}$ In recent years, the most unfavourable tendencies are observed in expenditure on research and development. Apart from low expenditure on R\&D by foreign companies located in Po-

2 Losses are not compensated for by profit re-investment. Profits flow out while losses stay. 
Table 8. FDI in Poland in selected types of business activity of the direct investment entities, 2009-2012 (million EUR)

\begin{tabular}{|c|c|c|c|c|c|c|}
\hline Code & $\begin{array}{c}\text { Type of } \\
\text { business } \\
\text { activity }\end{array}$ & Year & Equity & $\begin{array}{l}\text { Reinvested } \\
\text { profits }\end{array}$ & $\begin{array}{l}\text { Other capital (debt } \\
\text { securities, credits) }\end{array}$ & $\begin{array}{l}\text { Total capital } \\
\text { inflows }\end{array}$ \\
\hline \multirow[t]{4}{*}{ C3395 } & $\begin{array}{l}\text { Processing } \\
\text { industry }\end{array}$ & 2009 & 898.2 & 1945.7 & 515.6 & 3359.5 \\
\hline & & 2010 & -1133.7 & 1706.8 & -89.8 & 483.3 \\
\hline & & 2011 & 613.7 & 2515.9 & 613.8 & 3743.5 \\
\hline & & 2012 & 605.5 & 2211.3 & -20.1 & 2796.7 \\
\hline \multirow[t]{4}{*}{ F4395 } & $\begin{array}{l}\text { Building } \\
\text { industry }\end{array}$ & 2009 & 178.7 & 86.8 & 150.6 & 416.1 \\
\hline & & 2010 & 695.5 & 143.0 & 205.7 & 1044.1 \\
\hline & & 2011 & 1855.5 & -165.1 & 1679.0 & 3369.4 \\
\hline & & 2012 & 343.7 & -708.9 & 248.0 & -117.3 \\
\hline \multirow[t]{4}{*}{ K6695 } & $\begin{array}{l}\text { Finance and } \\
\text { insurance } \\
\text { business }\end{array}$ & 2009 & -613.3 & 1502.4 & 727.5 & 1616.6 \\
\hline & & 2010 & -1127.2 & 963.9 & -817.2 & -980.5 \\
\hline & & 2011 & 1064.8 & 1258.5 & 1072.7 & 3396.1 \\
\hline & & 2012 & 1854.2 & 1835.4 & 146.9 & 3836.5 \\
\hline \multirow[t]{4}{*}{ M7200 } & $\begin{array}{l}\text { Research and } \\
\text { development } \\
\text { activities }\end{array}$ & 2009 & 2.2 & 0.4 & 2.4 & 5.0 \\
\hline & & 2010 & -4.6 & 3.3 & -11.6 & -12.9 \\
\hline & & 2011 & 15.8 & 0.8 & -2.0 & 14.6 \\
\hline & & 2012 & -1.6 & 3.3 & 0.5 & 2.2 \\
\hline
\end{tabular}

Source: Author's compilation based on NBP data (2008-2012).

land in 2010 and 2012, disinvestment was noted in the field of equity in the years 2010-2011, while foreign credits were on the increase (Table 8).

According to the NBP data, in 2012 the biggest FDI inflow came from Germany (EUR 3.5 billion) and France (EUR 3.1 billion), whereas the biggest withdrawal of investors (disinvestment) concerned, among others, Luxembourg (EUR -3.2 billion) and the Netherlands (EUR -1.7 billion). In 2012, FDI came, first of all, to the entities involved in financial and insurance activities (EUR 3.8 billion) and the processing industry (EUR 2.8 billion). The outflow was observed in the sector of professional, scientific and technical activities (mainly the activities of holdings) (EUR -3.7 billion) (NBP 2012). 


\section{CONCLUSIONS}

This paper focuses on the analysis of the FDI- GDP relationship from the point of view of the Keynesian, neoclassical and new theories of growth, and outlines empirical research results in the field of uni- and bi-directional relationships occurring between FDI and GDP. The mutual relationships among the factors of production, including FDI and GDP, for Poland in the years 1992-2012 were investigated with the use of the Cobb-Douglas production function and the VECM model. An analysis of impulse responses and variance decomposition were carried out in order to define sensitivity and the degree of explanation of the examined variables. Conclusions from the econometric analysis were supplemented with the structure characteristic of the FDI flowing to Poland in the years 19992012.

The following conclusions can be drawn from the study:

1. Verification of the production model (GDP), taking into account explanatory variables, i.e., GFCF, Employment, FDI, Exports and R\&D, and the conducted tests confirmed the non-stationarity of time series and the occurrence of co-integration, which allowed us to use the VECM model. The VECM model, impulse responses, and the variance decomposition analysis confirmed bi-directional relationships between FDI and GDP in Poland.

2. The analysis of the impulse responses of both GDP and FDI indicates that, over time, the impulses (stimuli) of the five examined factors exerted mostly a positive and growing impact on their future values.

3. The analysis of the GDP sensitivity coefficients revealed that in the first year after the occurrence of the financial shock, a significant impact of FDI, exports, and GFCF was noted, whereas after 10 years, the impact of FDI, gross fixed capital formation, and R\&D was noted. On the other hand, the analysis of the FDI sensitivity coefficients indicates that in the first year after the shock, it reacted most strongly to the impulses from exports and expenditure on R\&D, whereas after 10 years to GFCF and exports.

4. The variance decomposition calculations for the variable GDP show that GDP was explained to the largest degree by GFCF, FDI and employment, both in the first and the $10^{\text {th }}$ year of the forecast. Over time, it was observed that employment increasingly accounts for GDP. "Efficiency" of employment in affecting GDP was growing over time. Employment is the long-run variable of growth. FDI is also in the group of factors of the long-run effect, and in this respect, it is comparable with employment.

5. The variance decomposition for the variable FDI indicates that GDP was the main explanatory factor. The significance of GDP for accounting for the changes in FDI was immense. In the first year of the forecast, as much as $72.1 \%$ of 
FDI changes, and as much as $47.2 \%$ in the $10^{\text {th }}$ year were accounted for by GDP changes.

6. The relationships are bi-directional between FDI and GDP in Poland. However, the impact of GDP is stronger with respect to attracting FDI inflows than the impact of FDI on GDP. A weaker, though confirmed impact of FDI on economic growth results from the structure of FDI inflows, which are characterised by a considerable share of debt securities.

7. The development policy of Poland should focus on three essential determinants of growth, namely employment growth, attracting FDI with emphasis on the better type of the inflowing investment, and productivity of domestic investment.

\section{REFERENCES}

Acaravci, A. - Ozturk, I. (2012): Foreign Direct Investment, Export and Economic Growth: Empirical Evidence from New EU Countries. Romanian Journal of Economic Forecasting, 2: 52-67.

Aizeman, J. - Noy, L. (2006): FDI and Trade - Two Way Linkages? The Quarterly Review of Economics, 46(3): 317-337.

Bieńkowski, W. - Weresa, M. A. - Radło, M. J. (2010): Konkurencyjność Polski na tle zmian gospodarczych w krajach OECD. Ewolucja znaczenia czynników konkurencyjności (Poland Competitiveness against Economic Changes in OECD Countries. Evolution of Meaning of Factors of the Competitiveness). Warsaw: Warsaw School of Economics Publishing House.

Blomström, M. - Kokko, A. (1998): Multinational Corporations and Spillovers. Journal of Economic Surveys, 12: 247-277.

Blomström, M. - Kokko, A. - Zejan, M. (2000): Foreign Direct Investment: Firms and Host Country Strategies. London: Macmillian Press, pp. 15-41.

Borensztein, E. - De Gregorio, J. - Lee, J. W. (1988): How does Foreign Direct Investment Affect Growth? Journal of International Economics, 45(1): 115-135.

Brems, H. (1970): A Growth Model of International Direct Investment. American Economic Review, 60(3): 320-331.

Chowdhry, A. - Mavrotas, G. (2009): FDI and Growth: What Causes What? The World Economy, 29(1): 42-58.

Damijan, J. - Kostevec, Č. - Rojec, M. (2013): Global Supply Chains at Work in Central and Eastern European Countries: Impact of FDI on Export Restructuring and Productivity Growth. Centre for Institutions and Economic Performance, KU Leuven, LICOS Discussion Paper, 332/2013,

De Mello, L. R., Jr. (1997): Foreign Direct Investment in Developing Countries and Growth: A Selective Survey. The Journal of Development Studies, 34(1): 1-24.

Dimelis, S. P. - Papaioannou, S. K. (2010): FDI and ICT Effects on Productivity Growth: A Comparative Analysis of Developing and Developed Countries. The European Journal of Development Research, (EADI) UK, 22(1): 79-96.

Driffied, N. - Jindra, B. (2012): Challenging the Production Function Approach to Assess the Developmental Effects of FDI. European Journal of Development Research and Training Institutes (EADI), Geneva, 24(1): 32-37. 
Dunning, J. H. (1998): Transactional Corporations: An Overview of Relations with National Governments. New Political Economy, 3(2): 280-284.

Dunning, J. H. - Narula, R. (1996): The Investment Development Path Revisited: Some Emerging Issues. In: Dunning, J. H. - Narula, R. (eds): Foreign Direct Investment and Government Catalysts for Economic Restructuring. London: Routledge, pp.1-41.

Ericsson, J. - Irandoust, M. (2001): On the Causality between Foreign Direct Investment and Output: A Comparative Study. The International Trade Journal, 15(1): 122-132.

Estrin, S. (2014): How does Foreign Direct Investment Affect Domestic Enterpreneurship. In: Kołodko G. W. (ed.): Managament and Economic Policy for Development. New York: Nova Science Publishers Inc., pp. 53-72.

Forte, R. - Sarmento, P. (2014): Does FDI Increase Market Concentration? An Evaluation of the Portuguese Manufacturing Industries. Acta Oeconomica, 64(4): 463-480.

Górecki, B. R. (2010): Ekonometria. Podstawy Teorii i Praktyki (Econometrics. Bases of the Theory and Practice). Warsaw: Wydawnictwo Key Text, pp. 219-222.

Gurgul, H. - Lach, Ł. (2009): Związki przyczynowe pomiędzy bezpośrednimi inwestycjami zagranicznymi w Polsce a podstawowymi wskaźniki makroekonomiczne (wyniki badań empirycznych) (Causalities between Foreign Direct Investment in Poland and Basic Macroeconomic Indicators (Empirical Findings)). Ekonomia Menadżerska, 6: 77-91.

Güngór, H. - Katricialogu, S. T. - Mercan, M. (2014): Revisiting the Nexus between Financial Development, FDI, and Growth: New Evidence from Second Generation Econometric Procedures in the Turkish Context. Acta Oeconomica, 64(1): 73-89.

Hermes, N. - Lensink, R. (2003): Foreign Direct Investment, Financial Development and Economic Growth. The Journal of Development Studies, 40(1): 142-163.

Herzer, D. - Klasen, S. - Nowak-Lehmann, F. (2008): In Search of FDI-Led Growth in Developing Countries: The Way Forward. Economic Modelling, 25(5): 793-910.

Karaszewski, W. (2004): Bezpośrednie inwestycje zagraniczne. Polska na tle świata (Foreign Direct Investment. Poland against the Word). Toruń: Dom Organizatora.

Keynes, J. M. (1936): The General Theory of Employment, Interest and Money. London: MacMillan.

Kida, N. M. (2014): Foreign Direct Investment, Environment and Economic Growth. Acta Universitatis Danubius Oeconomica, 10(4): 31-41.

Kołodko, G. W. (2000): Globalization and Catching-up: From Recession to Growth in Transition Economies. IMF Working Paper, WP/00/100: 6-37.

Kosztowniak, A. (2013): Foreign Direct Investment as a Factor of Economic Growth in Poland. Empirical Analysis for the Period 1995-2012. In: Advances in Economics and Business (USA: Horizon Research Publishing), 1(2): 206-215.

Kufel, T. (2011): Ekonometria (Econometrics). Warszawa: Wydawnictwo Naukowe PWN, pp. $169-170$.

Kusideł, E. (2010): Modele wektorowo-autoregresyjne VAR. Metodologia i zastosowanie (Vector Autoregressive Models VAR. Methodology and the Application). In: Suchecki, B. (ed.): Dane panelowe i modelowanie wielowymiarowe w badaniach ekonomicznych (Panel Data and Multidimensional Modelling in the Economic Research). Łódź: Absolwent, Vol. 3, pp. 33-97.

Marona, B. - Bieniek, A. (2013): Wykorzystanie modelu VECM do analizy wpływu bezpośrednich inwestycji zagranicznych na gospodarkę Polski w latach 1996-2010 (The Analysis of the Influence of Foreign Direct Investment on Polish Economy in 1996-2010 Using VECM Methodology). Acta Universitatis Nicolai Copernic-Ekonomia, XLIV( 2): 333-350.

Mickiewicz, T. - Bishop, K. - Varblane, U. (2004): Financial Constraints in Investment. Panel Data Results From Estonia, 1995-1999. Acta Oeconomica, 54(4): 425-449. 
Misztal, P. (2012): Bezpośrednie inwestycje zagraniczne jako czynnik wzrostu gospodarczego w Polsce. (Foreign Direct Investment as a Factor of Economic Growth in Poland). Finanse, 1(5): 9-26.

NBP (2014): Zagraniczne inwestycje bezpośrednie w Polsce, za lata 2008-2012 (Foreign Direct Investment in Poland in Years 2008-2012), http://www.nbp.pl/home.aspx?f=/publikacje/zib/ zib.html

OECD (2014): OECDStat., http://www.oecd.org/statistics/

Ozturk, I. (2007): Foreign Direct Investment-Growth Nexus: A Review of the Recent Literature. International Journal of Applied Econometrics and Quantitative Studies, 4(2): 79-98.

Roman, M. D. - Padureanu, A. (2012): Models of Foreign Direct Investments Influence on Economic Growth. Evidence from Romania. International Journal of Trade, Economics and Finance, 3(1) February: 25-29.

Smarzynska Javorcik, B. (2004): Does Foreign Direct Investment Increase the Productivity of Domestic Firms? In Search of Spillovers through Backward Linkages. The American Economic Review, 94(3): 605-627.

Solow, R. M. (1999): Neoclassical Growth Theory. In: Taylor, J. B. - Woodford, M. (eds): Handbook of Macroeconomics. Amsterdam: Elsevier.

Welfe, A. (2003): Ekonometria. Metody i ich zastosowanie (Econometrics. Method and Applying them). Warszawa: Wydawnictwo Naukowe PWN.

Weresa, M. A. (2009): Innowacje jako źródło przewagi konkurencyjnej w gospodarce opartej na wiedzy (Innovation as a Source of Competitive Advantage in the Knowledge-Based Economy). In: Mińśka-Struzik, E. - Rynarzewski, T. (eds): Szoki technologiczne w gospodarce światowej (Technology Shocks in World Economy). Poznań: Wydawnictwo UE.

Witkowska, J. (2011): Rola kapitału zagranicznego w modernizacji gospodarki nowych krajów członkowskich Unii Europejskiej. Aspekty porównawcze (The Role of Foreign Capital in Modernising the Economies of New EU Member States. Comparative Aspects). PTE (Polish Economic Society), Zeszyty Naukowe, 9: 107-122.

Wojtyna, A. (2000): Ewolucja keynesizmu a glówny nurt ekonomii (The Evolution of Keynesianism and the Mainstream Economics). Warszawa: Wydawnictwo Naukowe PWN.

Wojtyna, A. (2008): Instytucje a polityka ekonomiczna $w$ krajach na średnim poziomie rozwo$j u$ (Institutions and Economic Policies in Countries on the Average Level of Development). Warszawa: Wydawnictwo Naukowe PWN. 


\section{APPENDIX}

\section{Results of the VECM structural parameter estimation}

\begin{tabular}{|c|c|c|c|c|}
\hline \multicolumn{5}{|c|}{$\begin{array}{l}\text { VECM (vector error correction model)-based system, lag order }-2 \\
\text { Estimation, maximum likelihood for the observation 1994-2012 }(\mathrm{T}=19) \text {; } \\
\text { Co-integration order }=1\end{array}$} \\
\hline \multicolumn{5}{|c|}{ Case 3: Unrestricted absolute term (const) } \\
\hline \multicolumn{3}{|c|}{$\begin{array}{c}\text { beta } \\
\text { (Co-integrating vectors. Estimate errors in parantheses) }\end{array}$} & \multicolumn{2}{|c|}{$\begin{array}{c}\text { alpha } \\
\text { (adjustment vectors) }\end{array}$} \\
\hline 1_GDP & 1.0000 & $(0.0000)$ & 1_GDP & 0.22017 \\
\hline 1_GFCF & -0.25007 & $(0.0013128)$ & 1_GFCF & -0.51007 \\
\hline 1_Employ & 0.57717 & $(0.0057850)$ & 1_Employ & -0.23148 \\
\hline 1_FDI & 0.031447 & $(0.00055241)$ & $1 \_$FDI & -7.4082 \\
\hline 1_Exports & -0.19668 & $(0.00060096)$ & 1_Exports & 11.967 \\
\hline 1 R\&D & -0.19528 & $(0.0024330)$ & $1 \_\mathrm{R} \_\mathrm{D}$ & -4.5365 \\
\hline
\end{tabular}

Log likelihood $=291.7037$

Covariance matrix determinant $=1.8614801 \mathrm{e}-021$;

$\mathrm{AIC}=-22.4951 ; \mathrm{BIC}=-18.6180 ; \mathrm{HQC}=-21.8390$ Equation 1: d_1_GDP

\begin{tabular}{|c|c|c|c|c|c|}
\hline & Coefficient & Standard error & t-distribution & $\mathrm{p}$ value & \\
\hline const & -3.47672 & 14.3429 & -0.2424 & 0.81293 & \\
\hline d_1_GDP_1 & -1.33773 & 1.64958 & -0.8110 & 0.43459 & \\
\hline d_1_GFCF_1 & 0.37559 & 0.334313 & 1.1235 & 0.28516 & \\
\hline d_1_Employ_1 & -0.307133 & 0.433739 & -0.7081 & 0.49361 & \\
\hline d_1_FDI_1 & 0.00626917 & 0.019827 & 0.3162 & 0.75777 & \\
\hline d_1_Exports_1 & 0.067652 & 0.112777 & 0.5999 & 0.56074 & \\
\hline d_1_R\&D_1 & 0.0811001 & 0.19417 & 0.4177 & 0.68422 & \\
\hline $\mathrm{EC} 1$ & 0.220167 & 0.892046 & 0.2468 & 0.80960 & \\
\hline \multicolumn{2}{|c|}{$\begin{array}{l}\text { Arithmetic mean of dependent } \\
\text { variable }\end{array}$} & 0.043571 & \multicolumn{2}{|c|}{$\begin{array}{l}\text { Standard deviation for } \\
\text { dependent variable }\end{array}$} & 0.017904 \\
\hline \multicolumn{2}{|c|}{ Sum of squared residuals } & 0.003940 & \multicolumn{2}{|c|}{ Residual standard error } & 0.018925 \\
\hline \multicolumn{2}{|c|}{$\begin{array}{c}\text { Coefficient of determination } \\
\text { of R2 } \\
\end{array}$} & 0.317213 & \multicolumn{2}{|c|}{ Corrected R squared } & -0.117288 \\
\hline \multicolumn{2}{|c|}{ Residual autocorrelation - rho1 } & 0.060994 & \multicolumn{2}{|c|}{ Durbin-Watson Statistic } & 1.678898 \\
\hline \multicolumn{6}{|c|}{ Equation 2: d_1_GFCF } \\
\hline & Coefficient & Standard error & t-distribution & $\mathrm{p}$ value & \\
\hline const & 8.31393 & 56.4339 & 0.1473 & 0.88554 & \\
\hline d_1_GDP_1 & -3.94342 & 6.49048 & -0.6076 & 0.55581 & \\
\hline d_1_GFCF_1 & 1.34875 & 1.3154 & 1.0254 & 0.32722 & \\
\hline d_1_Employ_1 & -0.925237 & 1.7066 & -0.5422 & 0.59852 & \\
\hline d_1_FDI_1 & 0.0489051 & 0.0780119 & 0.6269 & 0.54352 & \\
\hline
\end{tabular}




\begin{tabular}{|c|c|c|c|c|c|}
\hline d_1_Exports_1 & 0.210127 & 0.443734 & 0.4735 & \multicolumn{2}{|l|}{0.64509} \\
\hline d_1_R\&D_1 & 0.20866 & 0.763985 & 0.2731 & \multicolumn{2}{|l|}{0.78982} \\
\hline $\mathrm{EC} 1$ & -0.510068 & 3.50987 & -0.1453 & \multicolumn{2}{|l|}{0.88708} \\
\hline \multicolumn{2}{|c|}{$\begin{array}{l}\text { Arithmetic mean of dependent } \\
\text { variable }\end{array}$} & 0.064559 & \multicolumn{2}{|c|}{$\begin{array}{l}\text { Standard deviation for } \\
\text { dependent variable }\end{array}$} & 0.083133 \\
\hline \multicolumn{2}{|c|}{ Sum of squared residuals } & 0.060990 & \multicolumn{2}{|c|}{ Residual standard error } & 0.074462 \\
\hline \multicolumn{2}{|c|}{$\begin{array}{l}\text { Coefficient of determination of } \\
\text { R2 }\end{array}$} & 0.509726 & \multicolumn{2}{|c|}{ Corrected R squared } & 0.197734 \\
\hline \multicolumn{2}{|c|}{ Residual autocorrelation - rhol } & 0.120329 & \multicolumn{2}{|c|}{ Durbin-Watson Statistic } & 1.585339 \\
\hline \multicolumn{6}{|c|}{ Equation 3: d_1_Employ } \\
\hline \multicolumn{2}{|r|}{ Coefficient } & Standard error & t-distribution & \multicolumn{2}{|l|}{$\mathrm{p}$ value } \\
\hline const & 3.69194 & 15.5672 & 0.2372 & \multicolumn{2}{|l|}{0.81689} \\
\hline d_1_GDP_1 & 1.34166 & 1.79039 & 0.7494 & \multicolumn{2}{|l|}{0.46936} \\
\hline d_1_GFCF_1 & -0.260122 & 0.362852 & -0.7169 & \multicolumn{2}{|l|}{0.48839} \\
\hline d_1_Employ_1 & 0.770619 & 0.470764 & 1.6370 & \multicolumn{2}{|l|}{0.12990} \\
\hline d_1_FDI_1 & 0.00451551 & 0.0215195 & 0.2098 & \multicolumn{2}{|l|}{0.83763} \\
\hline d_1_Exports_1 & -0.042872 & 0.122404 & -0.3503 & \multicolumn{2}{|l|}{0.73277} \\
\hline d_1_R\&D_1 & -0.0857312 & 0.210745 & -0.4068 & \multicolumn{2}{|l|}{0.69196} \\
\hline $\mathrm{EC} 1$ & -0.231485 & 0.968195 & -0.2391 & \multicolumn{2}{|l|}{0.81543} \\
\hline \multicolumn{2}{|c|}{$\begin{array}{l}\text { Arithmetic mean of dependent } \\
\text { variable }\end{array}$} & 0.004043 & \multicolumn{2}{|c|}{$\begin{array}{l}\text { Standard deviation for } \\
\text { dependent variable }\end{array}$} & 0.022385 \\
\hline \multicolumn{2}{|c|}{ Sum of squared residuals } & 0.004641 & \multicolumn{2}{|c|}{ Residual standard terror } & 0.020540 \\
\hline \multicolumn{2}{|c|}{ Coefficient of determination of R2 } & 0.485476 & \multicolumn{2}{|c|}{ Corrected R squared } & 0.158051 \\
\hline \multicolumn{2}{|c|}{ Residual autocorrelation - rho1 } & -0.060290 & Durbin-Wats & on Statistic & 2.088866 \\
\hline & & Equation 4: d_1 & FDI & & \\
\hline & Coefficient & Standard error & t-distribution & $\mathrm{p}$ value & \\
\hline const & 119.416 & 436.953 & 0.2733 & 0.78969 & \\
\hline d_1_GDP_1 & -16.3072 & 50.254 & -0.3245 & 0.75165 & \\
\hline d_1_GFCF_1 & 3.93735 & 10.1848 & 0.3866 & 0.70643 & \\
\hline d_1_Employ_1 & -16.6883 & 13.2138 & -1.2629 & 0.23272 & \\
\hline d_1_FDI_1 & -0.0466368 & 0.604025 & -0.0772 & 0.93984 & \\
\hline d_1_Exports_1 & 1.61294 & 3.43572 & 0.4695 & 0.64791 & \\
\hline d_1_R\&D_1 & 3.72369 & 5.91533 & 0.6295 & 0.54188 & \\
\hline $\mathrm{EC} 1$ & -7.4082 & 27.176 & -0.2726 & 0.79021 & \\
\hline $\begin{array}{r}\text { Arithmetic me } \\
\text { va }\end{array}$ & $\begin{array}{l}\text { in of dependent } \\
\text { able }\end{array}$ & 0.066469 & $\begin{array}{r}\text { Standard de } \\
\text { dependent }\end{array}$ & $\begin{array}{l}\text { viation for } \\
\text { variable }\end{array}$ & 0.494999 \\
\hline Sum of squ & red residuals & 3.656344 & Residual stan & dard terror & 0.576537 \\
\hline Coefficient of $d$ & ermination of $\mathrm{R} 2$ & 0.170978 & Corrected $\mathrm{F}$ & squared & -0.356581 \\
\hline Residual autoc & rrelation - rho1 & 0.032008 & Durbin-Wats & on Statistic & 1.553567 \\
\hline
\end{tabular}




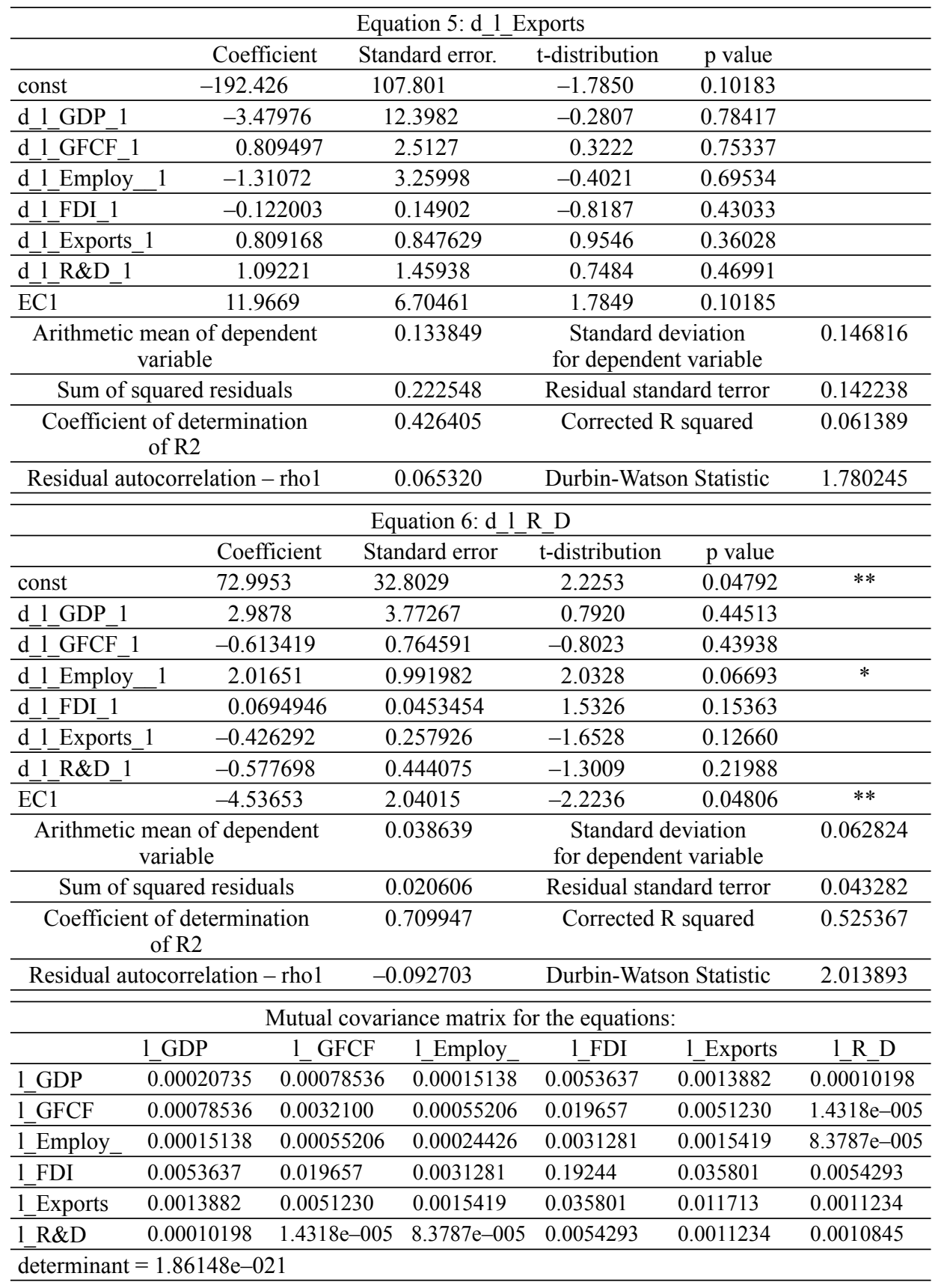

Source: Author's compilation based on OECD StatExtracts (2014), with the use of the Gretl 1.9.14. program. 